\title{
Longitudinal Effects of Informal Language in Formal L2 Instruction
}

\section{Hirofumi Asada \\ Fukuoka Jogakuin University}

This study investigates the longitudinal effects of informal language contact on formally instructed L2 learners through multiple approaches which include quantitative and qualitative data sources. It focuses on the use of the aspect markers -te iru and -te ru (the reduced form of -te iru) in Japanese oral discourse by Chinese exchange students (NNSs). The quantitative data for conversational tasks was transcribed and analyzed using the Child Language Data Exchange System (CHILDES), and the frequency of occurrence and variation of aspect markers were compared with those of Japanese university students (NSs). Qualitative data from follow-up interviews and pre- and postsurveys was also analyzed. The findings were that: a) NSs used -te ru far more frequently and with more variation than -te iru; and b) NNSs used -te ru less than -te iru over a period of one year. However, the use of -te ru steadily increased with longer stays in Japan. The implications of the results for sociolinguistic theories are also discussed.

本研究は、言語接触の観点から、本国でのフォーマルな日本語学習から日本でのイン フォーマルな言語環境に接触した外国人留学生の使用するアスペクトの変化について縦 断的に調査したものである。具体的には、談話資料、フォローアップ・インタビュー、 アンケートで得たデータを複合アプローチを用いて分析した。談話分析に関しては、 CHILDESを使用し、同世代の日本人大学生と比較した。その結果、母語話者の発話で は、頻度および領域の両面において、「テル」が「テイル」を凌駕していること、非母語 話者の発話では、「テル」より「テイル」が多用されているが、滞日期間が長くなるにつ れて「テル」の使用が増える傾向にあることがわかった。

JALT Journal, Vol. 28, No. 1, May, 2006 
$\neg$ here are growing numbers of exchange students studying a second language (L2). Taking Japan as an example, of the nearly 173,000 international students who came in 2004 (Immigration Bureau, 2005), a significant number participated in exchange programs which promoted linguistic and cultural learning. In the field of second language acquisition (SLA), however, much of the research has focused on either foreign language learning in the learner's home country, formal classroom learning in the target language setting, or acquisition in a natural environment. Such distinctions do not cover exchange students who have received formal language instruction in their home country and are then, upon arrival in their host country, immersed totally or with some degree of tutoring in the target speech community. These variations of learning contexts are termed study abroad and must be considered as another salient issue in SLA research (see Freed, 1995).

Much of the empirical research to date has been conducted to explore the linguistic benefits of a study-abroad context from different perspectives. Dyson (1988) found that British students who had spent a year studying in France, Germany, or Spain gained considerable growth in L2 proficiency. Lapkin, Hart, and Swain (1995) investigated Canadian English-speaking students who participated in a 3-month bilingual exchange program in Quebec, a French-speaking community. They observed that students with lower French language proficiency were likely to make greater gains as a result of immersion in a French environment. The findings of both studies above derive from pre- and posttest scores. In contrast, using the Oral Proficiency Interview (OPI), Lafford (1995) compares communicative strategies by Anglo students of Spanish who spent a semester studying abroad with those of a control group in a formal classroom context in their home country. The findings suggest that incountry experience broadens the repertoire of communicative strategies available to students and helps them become better conversationalists. Barron (2003) discusses the development of L2 pragmatic competence focusing on Irish students of German who spent 10 months in Germany. The primary findings of the study indicate that exposure to L2 input in the target culture triggers development of pragmatic competence in the investigated areas of discourse structure, pragmatic routines, and internal modification.

There also exists a significant amount of research in relation to Japanese as a second language (JSL) in a study-abroad context. Marriott (1993, 1995) addresses the acquisition of sociolinguistic competence by Australian secondary level exchange students who spent a year in Japan. Both 
studies explored the acquisition of different sociolinguistic variables through analysis of pre- and/or postinterview data. The results of these studies suggest that there is great variation in the acquisition of sociolinguistic competence among students, with considerable deviation from the target norm. Marriott (1997) also explored language learning experiences and the types of strategies adopted by Australians who spent a year as exchange students at the secondary level. The study revealed that the development of interaction networks, wherein the students were engaged with host families at home and peers at school, was an important factor in the acquisition of Japanese. Similarly, Hashimoto (1993) investigated how the host family was a source of input in the acquisition of communicative competence by an Australian secondary student in a yearlong exchange program. The case study found that the student developed some awareness of features of communicative language behaviors while in Japan. Following her return to Australia, her Japanese speech style began to incorporate more formal and politer variables. Moreover, Siegal (1994, 1995, 1996) describes the acquisition of pragmatic and stylistic competence with a focus on white Western middle-class women over a period of 18 months in Japan. The overall findings from these studies indicate that the female learners of Japanese created their own linguistic system based upon their perceptions of Japanese women, awareness of women's language, and their social position while in Japan, as well as the maintenance or construction of their own sense of identity within Japanese society.

It is important to note that many of the studies reviewed above have investigated the development of L2 proficiency or acquisition of L2 competence. However, the results are derived from the overseas experiences of L2 learners, particularly in communities with English or European languages as the native languages. Also, many of the studies in JSL contexts are concerned with secondary level exchange students as subjects. This younger age group invariably stays with host families and attends regular classes in high school; thus, as Hashimoto (1993) and Marriott (1995) point out, in their learning environment in their host country they may differ from other types of L2 learners such as tertiary level students. Furthermore, Freed (1995) argued that there has been little research to date concerning changes in syntactic features as a result of studying abroad.

In response to the limited research concerning structural changes in the L2, Regan (1995) addresses the effects of studying abroad on sociolinguistic variations, the changes in structural features in terms of the deletion of $n e$, the first particle of the negative in French. The general findings 
indicated that after a year of studying in France, consistent with native speaker usage, dramatic reductions of ne usage appeared in the speech of advanced Irish students of French.

\section{The Study}

Taking the limited number of studies discussed above into consideration, this study investigates the longitudinal effects of informal language contact on the Japanese oral discourse of Chinese university exchange students who had received formal JSL instruction in China. Language contact is often defined as how different languages influence each other when the languages are spoken in the same or adjoining areas. Sanada, Shibuya, Jinnouchi, and Sugito (1992) expand this definition so as to deal with contact between geographical or social varieties within a language and address changes in discourse or linguistic behavior as well as in phonologic, morphologic, and syntactic features.

The focus of this study is on linguistic changes of JSL learners, specifically the use of the aspect markers -te iru and -te ru (the reduced form of -te iru). The Japanese aspectual system has two major functions, action in progress and resultative state:

1) Progressive

Ann ga hashit-TE I-RU

Ann-Nom run-Progressive-Nonpast

"Ann is running."

2) Resultative

ringo ga kusat-TE I-RU

apple-Nom rot-Resultative-Nonpast

"The apple is rotten."

There have been numerous studies in relation to the acquisition of the -te iru form in JSL (Kurono, 1995; Sheu, 1997, 2000, 2002; Shibata, 1998; Shirai \& Kurono, 1998). These studies are largely concerned with the developmental process of different functions, including the two major functions illustrated above, in which data collection, however, is based on grammaticality judgment tests, storytelling with pictures, or inter- 
views with a native Japanese speaker. Furthermore, much of the previous research does not clearly show the extent to which the subjects received JSL instruction in either their home country or target culture.

Apart from the acquisition studies of the aspect marker -te iru described above, Sugaya (2003) reports that the predominant use of -te ru appeared in the longitudinal interview corpus of one NNS in a natural environment whose formal JSL instruction was limited before and during her stay in Japan. By contrast, extensive use of -te iru, which is normally introduced in formal JSL classrooms and textbooks, occurred in the speech of another NNS whose JSL instruction was initiated after her arrival in Japan. Moreover, Nishi and Shirai (2004) report that the reduced form -te $r u$ is extensively used in the native speech of Japanese. In addition, Lee (2002) and Hashimoto (2002) explore the code switching of -te iru and -te $r u$ by native Korean and native English JSL learners, respectively, according to the degree of intimacy with their interlocutors. The results of these studies, however, present conflicting evidence. The former study revealed more use of -te $r u$ in informal settings while the latter did not find any differences in -te iru and -te ru code switching. Moreover, Minegishi (1999) investigated native Japanese attitudes towards the use of contracted forms, including -te $r u$, in experimental designs. She found that the use of these forms was positively evaluated in informal settings.

With the groundwork in place from earlier investigations, this study addresses the following research questions:

1) How is the use of the aspect marker -te iru by JSL learners affected in the context of studying abroad?

2) How does the use of -te iru by JSL learners compare with that of native Japanese speaker controls?

3) What is implied by any changes or lack of changes in the use of -te iru by JSL learners?

\section{Method}

This study employs longitudinal and multiple approaches (Brewer \& Hunter, 1989; Gass \& Selinker, 1994; Hawkins, 1998; Krathwohl, 1998) which include quantitative and qualitative data sources (i.e., conversational tasks, follow-up interviews and pre- and postsurveys) in order to explore language shift by formally instructed JSL learners over a period of one year in a study-abroad context. 


\section{Participants}

Two groups participated in this study: four native speakers of Chinese (abbreviated as C1, C2, C3, and C4 hereinafter) and four native speakers of Japanese (abbreviated as J1, J2, J3, and J4 hereinafter). Both groups of participants were female students at the same university in Fukuoka, Japan. The four NNSs were exchange students who had majored in Japanese and had received formal JSL classroom instruction at a Chinese university for 1 year 7 months prior to their stay in Japan. All had been taught by native Chinese instructors and one native Japanese instructor. With the exception of their native Japanese instructor, the NNSs had had little contact with other native Japanese speakers outside the JSL classroom in China. They had never been to Japan prior to their arrival for this exchange program. A JSL proficiency test showed that the NNSs were at an intermediate level ${ }^{1}$. The ages of the NNSs ranged from 19 to 21 . They attended regular lectures along with a few JSL courses at a Japanese university from April 2002 to March 2003. The control group consisted of four NSs, all aged 19. All grew up in Fukuoka and had command of two varieties of Japanese, a local dialect and standard Japanese. The NNSs and NSs were paired as follows: C1/J1, C2/J2, C3/J3, C4/J4.

\section{Procedure}

Data collection began a few weeks after the NNSs arrived in Japan, and before they had met their NS counterparts. First, the NNSs completed a survey asking them to describe their personal details such as age, major, experiences with learning Japanese and interacting with Japanese native speakers in China, and travel experience outside of China. After this survey they took a language proficiency test to measure their knowledge of Japanese.

The conversational data and follow-up interviews were collected longitudinally at five points over a period of one year at their private university in Fukuoka from April 2002 to March 2003. First of all, the four pairs of NNS and NS participated in audio- and videotaped conversational tasks. The tasks involved discussing current university experiences or daily life for 30 minutes. The topics were chosen for their familiarity for facilitating interaction (cf. Asada \& Harrington, 1998; Marriott, 1993).

Within one week after each recording session, the researcher interviewed each participant individually in Japanese. These sessions were also recorded on audio- and videotape. During each interview the original videotapes were replayed to help the researcher ascertain the stu- 
dent's awareness of the processes that occurred at the time of interaction or "detect all significant deviations [from the norms to see] whether they have surfaced or not" (Neustupny, 1990, p. 31). Similarly, Enomoto and Marriott (1994) argue that "this method can provide data on processes which are not visible in surface linguistic forms" (p. 136). Furthermore, Fairbrother (2000) claims that "whereas most interview techniques require informants to give an often overgeneralized account of their experiences, the follow-up interview requires informants to be specific about particular events" (p. 35). The interviews followed the five stages suggested by Neustupny (1990, 1994a):

1. The interviewer explains the aim of the original study to be investigated and asks participants to give general comments on the original recording session. The interviewer also explains the procedure for follow-up interviews.

2. The interviewer asks participants to establish what expectations or knowledge they had before the original recording session in terms of the character of the session, and their own roles or those of other participants in the session.

3. The interviewer asks questions in relation to any particular events during the original recording session noted by the participants. Neustupny (1990) argues that "such questions normally elicit, apart from actually noted features, stereotype attitudes to the use of language in general and to particular problems of the recording session" (p. 32). It is important to remind the participants at this stage, however, that the researcher is focusing on "what happened at the moment of the interview rather than what the views of the subject are at the moment of the follow-up interview" (p. 33).

4. The interviewer asks a general question concerning awareness after the original recording session which "reinforces the subject's understanding that you wish to distinguish systematically between the time of the session and the time of the interview, while giving the subjects an opportunity to voice their observations on each point" ( $\mathrm{p}$. 33).

5. The interviewer asks the participant to give comments on the conclusions reached from the original recording session to test his/her hypotheses. 
Following the longitudinal data collection, the NNSs were asked to describe their activities in and out of university, their personal network, and their learning strategies and attitudes towards Japanese during their stay in Japan. This information was collected as additional data to supplement the base findings derived from the conversational tasks and follow-up interviews. Throughout the study, NNSs had little contact with their NSs on or off campus.

\section{Data Analysis}

The conversational data at three points ${ }^{2}$ were transcribed (following the coding rules of wakachi 2002 in Japanese Codes for Human Analysis of Transcripts (JCHAT)) and analyzed by using the Child Language Data Exchange System (CHILDES) (MacWhinney, 2000a, 2000b; Oshima-Takane \& MacWhinney, 1995). CHILDES consists of three separate but integrated tools: the CHAT transcription and coding format, the CLAN analysis program, and the actual database. The CLAN program is particularly useful in the analysis of speech data (e.g., counting word frequency or the typetoken ratio, searching for specified combinations of words, or describing specified words in context).

The program calculated the frequency of occurrence of the aspect markers (-te iru and -te ru) in different linguistic contexts, the total word types (i.e., the total number of unique words), and the total word tokens (i.e., the total number of words) used by each NNS participant. Then, the frequency of the aspect markers was divided by the total number of word types and word tokens in order to examine changes in the use of the NNSs' aspect markers in relation to overall vocabulary development and speech production (cf. Sawyer, 1992). The results of the NNSs' conversational data (see Table 1 ) were compared with those of their NS counterparts (see Table 2; cf. Johnstone, 2000).

The qualitative data for follow-up interviews were transcribed and then intergrated with the pre- and postsurveys before being interpreted along with the quantitative data for conversational tasks (Silverman, 2000). In this respect, the researcher carefully read the texts consisting of quantitative and qualitative data so as to categorize and synthesize the issues raised in the use of the aspect marker by formally instructed Chinese JSL learners as seen in Glesne (1999) and McDonough and McDonough (1997). 


\section{Results and discussion}

Concerning Research Question 1 about the longitudinal effects of informal language contact on the aspect marker -te iru used by formally instructed JSL learners, Table 1 shows that the NNSs used -te ru fewer times and with less variation than -te iru over a period of one year. However, the use of -te ru steadily increased as the stay of the NNSs in Japan lengthened. In particular, whereas all participants used -te iru from the beginning to Time 5 in conversational tasks, the overall use of -te ru occurred from Time 3 to Time 5. These results indicate a shift from -te iru to -te ru in the context of studying abroad for JSL learners who were formally instructed in their home country; while, as Sugaya (2003) mentions earlier, a NNS with little JSL instruction used -te ru far more frequently than -te iru.

Table 2 shows that NSs used -te $r u$ far more frequently and with more variation than -te iru. There were only 3 inflections of -te iru but 13 of -te ru, although $\mathrm{J} 1$ and $\mathrm{J} 4$ varied greatly in their use of -te iru and -te ru respectively. These findings support the extensive use of -te $r u$ in the native speech of Japanese (Nishi \& Shirai, 2004) and, in relation to Research Question 2, demonstrate a contrast to the results of NNSs in Table 1.

With respect to Research Question 3, change in the use of -te iru by JSL learners, that is, the dropping of the $i$ seems to be affected by the quality and quantity of JSL input before and during their stay in Japan. The NNSs report in both the presurvey and follow-up interviews that they had received formal JSL instruction using textbooks which focused on one of the honorific styles, the polite style referred to as the desu/masu style (Marriott, 1995). This honorific style promotes the use of the original aspect marker -te iru (Sugaya, 2003). This polite or formal speech style was also consistently employed in interactions with a native Japanese instructor in the classroom and, even if only a little, with other native Japanese speakers outside of the classroom. Thus, with little knowledge about the colloquial reduction form -te $r u$, the JSL participants used -te iru more frequently in their speech at the beginning of data collection. On the other hand, as Nishi and Shirai (2004) point out, -te $r u$ is extensively used in native speech of Japanese; therefore, it is expected that the JSL participants would be exposed to the reduced form quite often during their stay in Japan.

However, the mere exposure to the -te ru form while in Japan may not necessarily facilitate actual use of the form by JSL learners. It is of particular importance to uncover the participants' awareness of sociolinguistic norms for its use in the target speech community. Neustupny 


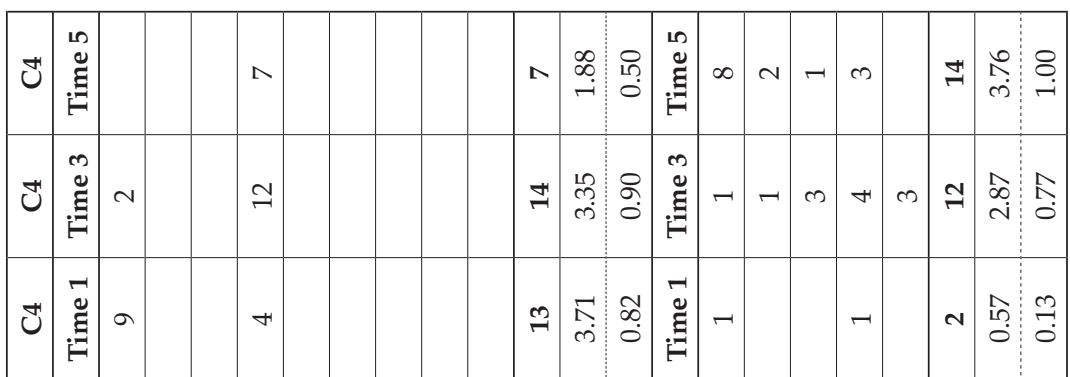

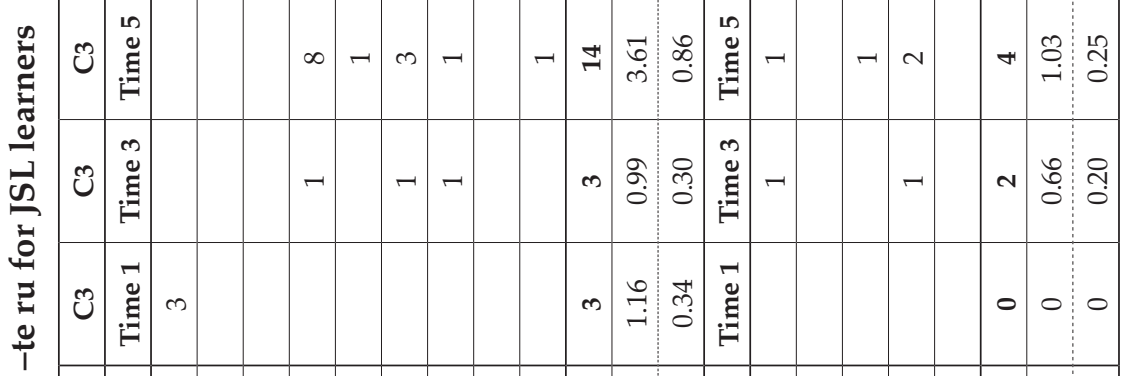

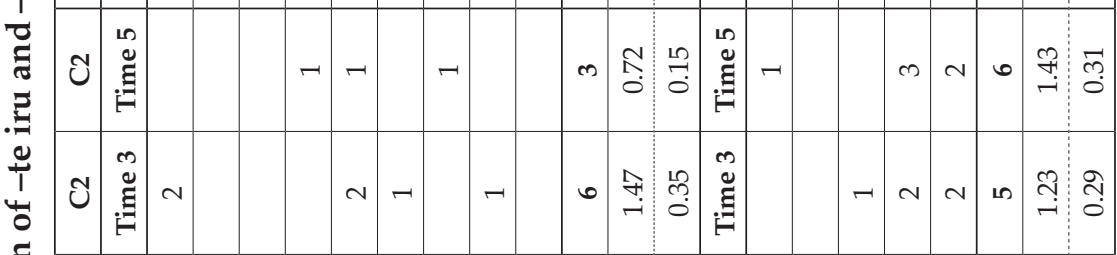

\begin{tabular}{|c|c|c|c|c|c|c|c|c|c|c|c|c|c|c|c|c|c|c|c|c|c|c|}
\hline $\mathcal{U}$ & $\underset{\Xi}{\stackrel{\Xi}{\Xi}}$ & $\infty$ & & $N$ & -1 & & & - & & & $\Lambda$ & $\stackrel{20}{\stackrel{2}{r}}$ & 용 & $\underset{\mathfrak{g}}{\vec{g}}$ & & & & & & 0 & 0 & 0 \\
\hline U & 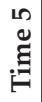 & & & & & & $\infty$ & & & & $\infty$ & $\bar{\sigma}$ & $\overrightarrow{0}$ & 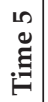 & - & & & & & -1 & ભి & $\stackrel{0}{0}$ \\
\hline U & $\underset{\mathfrak{g}}{m}$ & & & & -1 & & & & & & $r$ & ঐి & $\begin{array}{l}0 \\
0 \\
0\end{array}$ & $\begin{array}{c}m \\
\stackrel{\Xi}{\Xi} \\
\Xi\end{array}$ & - & & & & & -1 & ભి & $\begin{array}{l}0 \\
0 \\
0\end{array}$ \\
\hline U & 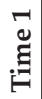 & $\theta$ & - & - & $N$ & & & & & & $\infty$ & 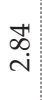 & $\begin{array}{l}\infty \\
0 \\
0\end{array}$ & 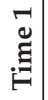 & & & & & & 0 & 0 & 0 \\
\hline & $\begin{array}{l}\sqrt[3]{5} \\
\stackrel{1}{0}\end{array}$ & 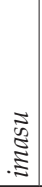 & 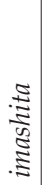 & 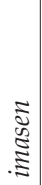 & 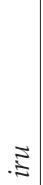 & \pm &. \pm & $\stackrel{\Xi}{\Xi}$ & 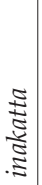 & 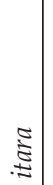 & సేّ & 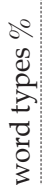 & $\mid \begin{array}{c}0 \\
0 \\
0 \\
0 \\
\frac{1}{0} \\
0 \\
0 \\
0 \\
0 \\
3\end{array}$ & 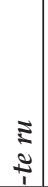 & $\stackrel{5}{2}$ & $\stackrel{ \pm}{\stackrel{\Xi}{\Xi}}$ & $\stackrel{\Xi}{\stackrel{\Xi}{E}}$ & $\frac{\tilde{B}}{3}$ & 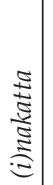 & సٓㅠ. & 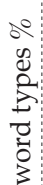 & $\begin{array}{l}\text { o } \\
0 \\
0 \\
0 \\
\text { v } \\
0 \\
0 \\
0 \\
0\end{array}$ \\
\hline
\end{tabular}




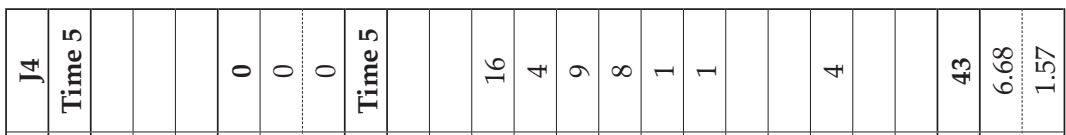

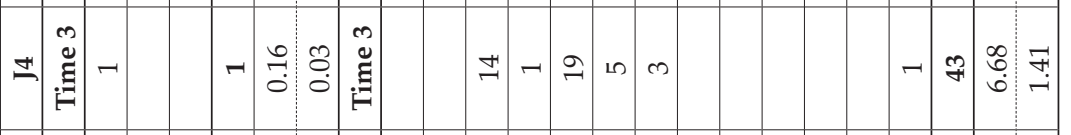

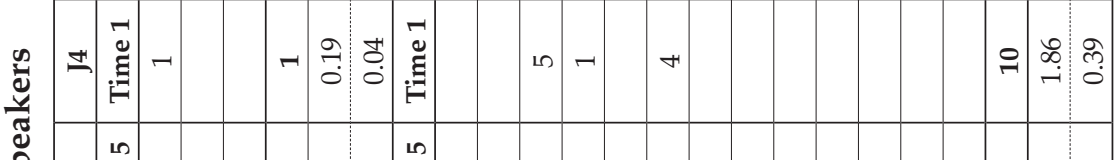

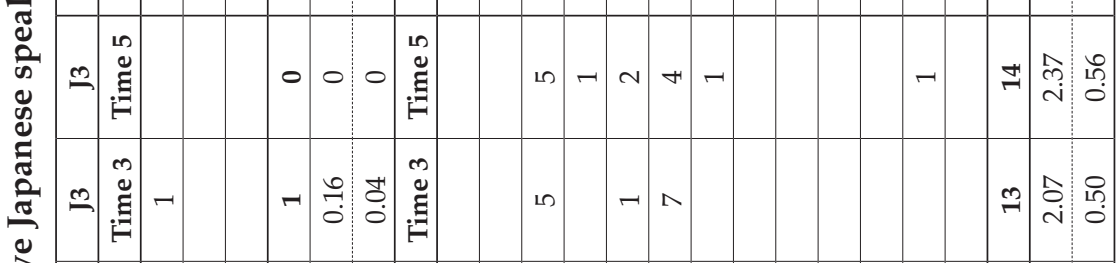

$\Xi$

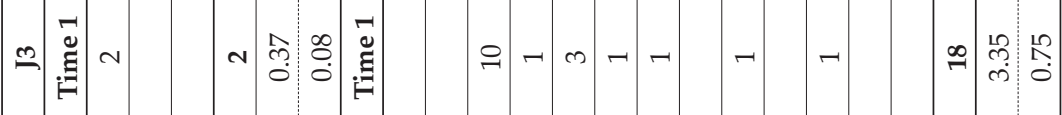

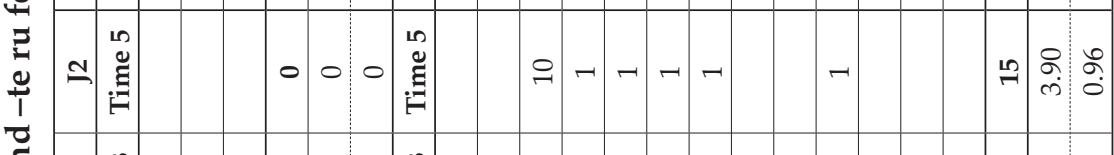

ร

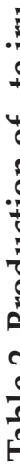

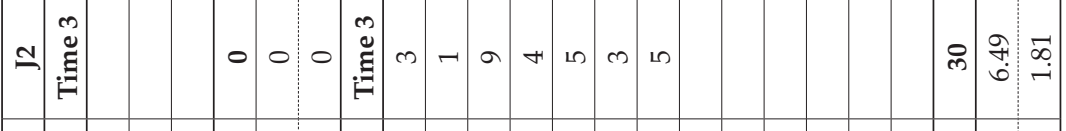

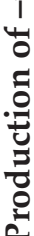

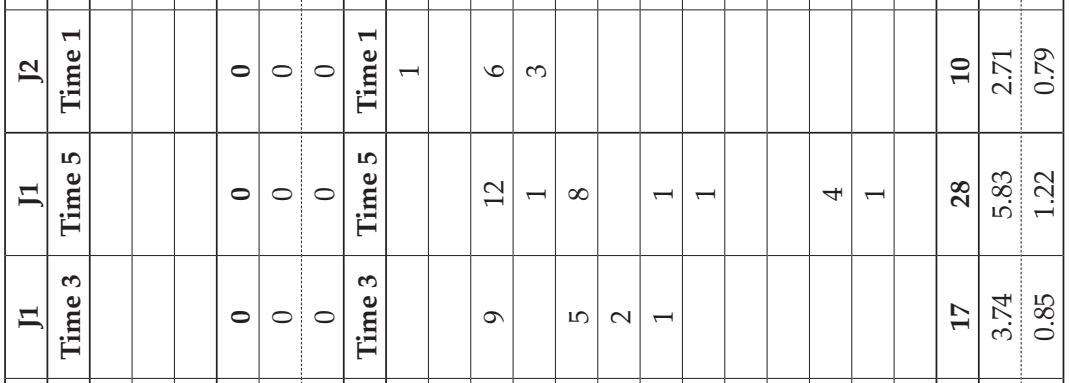

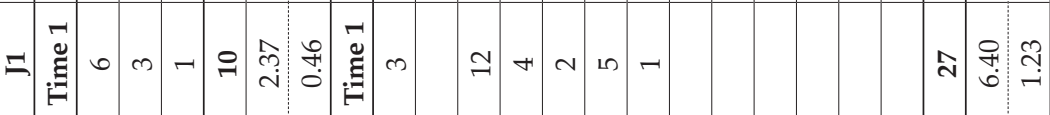

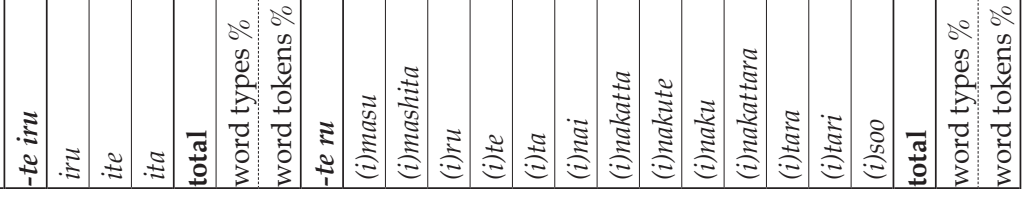


(1985b) proposes the concept of language management which defines norms as rules judged by participants to be correct for particular communicative situations. According to his model of language management (1985a, 1985b, 1994b, 1997a, 1997b), when deviations from norms occur in contact situations, these deviations may be noted or remain unnoted. If noted, they may be disregarded or often evaluated in a negative way, or occasionally result in positive evaluations. Then, plans for suitable action may be set to remove the deviations, and these plans may be subsequently implemented.

Why did the removal of the deviations (i.e. the use of -te iru) from the norms (i.e. the use of -te ru), that is, the shift from -te iru to -te ru occur in the speech of the NNSs while in Japan? An analysis of this study can be further discussed within two theoretical frameworks in sociolinguistics: speech accommodation and social network. The theory of speech accommodation addresses convergence and divergence, which are concerned, respectively, with shifting one person's language variety towards or away from another's (Giles, 2001). Giles and Powesland (1997) suggest that the process of speech accommodation is a reflection of one's desire for social approval and such behavior can be initiated only if potential rewards for the addresser are available.

This argument is confirmed in C4's (the most frequent user of -te ru among the four JSL participants) comments in follow-up interviews. She stated, "I just follow what native Japanese say." Although C4 did not necessarily show strong positive attitudes towards Japanese in the postsurvey, it may be beneficial for her to employ native speech norms for informal interactions. She also commented, "It is more natural and easier to say" (-te $r u$ than -te iru). As Crystal (1997) points out, ease of articulation is one of the social factors which affect language change. This may be a factor in C4's desire to have a better command of her Japanese and make it sound more native like.

Another sociolinguistic framework, which is relevant to this study, pertains to social network. This concept can be used to explain language variation in which individuals directly or indirectly interact with each other in or through social communities. In this model, as Holmes (1992) points out, an individual's speech is influenced by whether or not members of one's network interact with each other, and the range of different types of transactions in which one is involved.

During their stay in Japan, all of the NNS participants were involved in several types of part-time work in the service industry. As described in follow-up interviews, they wished to integrate into a community of 
native Japanese speakers outside of the university to have far more opportunities to talk with people whose age or gender were different from theirs. They felt this would not only improve their Japanese ability but broaden their view of contemporary Japanese society since they had limited teacher-student interaction or peer interaction in JSL courses or regular lectures and only a few close Japanese friends on campus. The participants reported that such part-time work indeed helped them to be exposed, albeit to a limited degree, to a variety of Japanese by interacting with native Japanese speakers such as customers, managers, or employees and promoted a deeper understanding of Japanese social life. The postsurvey also revealed that TV programs which included male and female interactions in natural settings or novels written in a conversational style were also helpful for their study of Japanese. These personal networks in which the participants were involved on and off campus affected their use of Japanese aspect markers.

\section{Conclusion}

This study has provided empirical evidence that during a year of study in Japan a linguistic shift occurred at the structural level in relation to the Japanese aspectual system in the speech of four Chinese university exchange students who had received formal JSL instruction in China. Although this study is limited in some ways, such as by the small number of participants and individual variations among the participants, the findings revealed that: a) NSs used -te $r u$ far more frequently and with more variation than -te iru, and b) NNSs used -te ru less than -te iru over a period of one year. However, the use of -te ru steadily increased with a longer stay in Japan. Some implications for the language shift were also discussed within a few notable sociolinguistic theoretical frameworks.

As for future directions, larger-scale studies with more qualitatively empirical substantiation are clearly needed to confirm the findings of this preliminary case study. Furthermore, it would be valuable to investigate whether JSL learners acquire pragmatic knowledge about using -te iru or -te ru differently according to their social relationship with their interlocutors as a result of their experience studying abroad (Hashimoto, 2002; Lee, 2002). Also, it may be necessary to explore the attitudes of native Japanese speakers with more of a focus on the use of -te iru and -te ru among contracted forms by JSL learners (cf. Minegishi, 1999).

Building upon the previous investigations mentioned above, further research is obviously needed to examine whether JSL learners appro- 
priately use -te iru or -te ru in different contexts, particularly in actual interactions with native Japanese speakers, and how native speakers simultaneously evaluate the different uses of -te iru and -te ru. Answers to these questions will contribute to a better understanding of the linguistic contexts in which these aspect markers should be used appropriately and thus, set a priority in JSL pedagogy in the home country as well as in the target community. Although this study sheds some light on how these aspect markers are used over time in a study-abroad context, it also shows the need for future research.

\section{Acknowledgements}

This study was supported in part by a Grant-in-Aid for Scientific Research C-2 from the Japan Society for the Promotion of Science (No. 13680366), the Ministry of Education.

Hirofumi Asada is a lecturer at Fukuoka Jogakuin University. His research interests include interaction between sociolinguistics and second language acquisition, particularly linguistic and cultural contact on formally instructed L2 learners. An earlier version of this paper was presented at the $29^{\text {th }}$ Annual Congress of the ALAA (Applied Linguistics Association of Australia) in Adelaide, Australia on July 17, 2004.

\section{Notes}

1. The 1999 Japanese Language Proficiency Test (second level) was used to measure the L2 knowledge of the NNSs when this study began in April 2002. All of the participants subsequently passed the first level of the Japanese Language Proficiency Test conducted in December 2002, jointly administered by the Association of International Education, Japan and the Japan Foundation.

2. For this study, three time spans (first, third, and fifth) were considered to be enough to reveal the changes in the aspect marker.

\section{References}

Asada, H., \& Harrington, M. (1998). Knowledge of gendered sentence-final forms in Japanese as a second language. Australian Review of Applied Linguistics, 15, 11-28. 
Barron, A. (2003). Acquisition in interlanguage pragmatics: Learning how to do things with words in a study abroad context. Amsterdam: John Benjamins.

Brewer, J., \& Hunter, A. (1989). Multimethod research: A synthesis of styles. Newbury Park, CA: Sage.

Crystal, D. (1997). The Cambridge encyclopedia of language (2 ${ }^{\text {nd }}$ ed.). Cambridge: Cambridge University Press.

Dyson, P. (1988). The year abroad. Report for the Central Bureau for Educational Visits and Exchanges. Oxford: Oxford University Language Teaching Centre.

Enomoto, S., \& Marriott, H. (1994). Investigating evaluative behavior in Japanese tour guiding interaction. Multilingua, 13 (1/2), 131-161.

Fairbrother, L. C. (2000). Analysis of intercultural interaction management within a party situation. Shakai Gengo Kagaku, 2 (2), 33-42.

Freed, B. F. (1995). Language learning and study abroad. In B. F. Freed (Ed.), Second language acquisition in a study abroad context (pp. 1-33). Amsterdam: John Benjamins.

Gass, S. M., \& Selinker, L. (1994). Second language acquisition: An introductory course. Mahwah, NJ: Lawrence Erlbaum Associates.

Giles, H. (2001). Speech accommodation. In R. Mesthrie (Ed.), Concise encyclopedia of sociolinguistics (pp. 193-196). Amsterdam: Elsevier.

Giles, H., \& Powesland, P. (1997). Accommodation theory. In N. Coupland \& A. Jaworski (Eds.), Sociolinguistics: A reader and coursebook (pp. 232-239). London: Macmillan Press.

Glesne, C. (1999). Becoming qualitative researchers: An introduction (2 ${ }^{\text {nd }}$ ed.). New York: Longman.

Hashimoto, H. (1993). Language acquisition of an exchange student within the homestay environment. Journal of Asian Pacific Communication, 4 (4), 209-224.

Hashimoto, T. (2002). Eigo bogowasha no sutairu kirikae [Code-switching by native English JSL learners]. Handai Shakaigengogaku Kenkyu Nooto, 4, 94-113.

Hawkins, R. (1998). Cross-sectional/longitudinal studies. In K. Johnson \& H. Johnson (Eds.), Encyclopedic dictionary of applied linguistics: A handbook for language teaching (pp. 93). Oxford: Blackwell.

Holmes, J. (1992). An introduction to sociolinguistics. London: Longman.

Immigration Bureau, the Ministry of Justice (2005, June). Heesee 16 nenmatsu genzai ni okeru gaikokujin toorokusha tookee ni tsuite [Registered-Alien statistics as of the end of 2004]. Tokyo: Author.

Johnstone, B. (2000). Qualitative methods in sociolinguistics. Oxford: Oxford University Press.

Krathwohl, D. R. (1998). Methods of educational \& social science research: An integrated approach ( $2^{\text {nd }}$ ed.). New York: Longman.

Kurono, A. (1995). Shokyuu nihongo gakushuusha ni okeru -te iru no shuutoku ni tsuite [On the acquisition of -te iru by elementary Japanese learners]. Nihongo Kyooiku, 87, 153-164. 
Lafford, B. A. (1995). Getting into, through, and out of a survival situation: A comparison of communicative strategies used by students studying Spanish abroad and "at home." In B. F. Freed (Ed.), Second language acquisition in a study abroad context (pp. 97-121). Amsterdam: John Benjamins.

Lapkin, S., Hart, D., \& Swain, M. (1995). A Canadian interprovincial exchange: Evaluating the linguistic impact of a three-month stay in Quebec. In B. F. Freed (Ed.), Second language acquisition in a study abroad context (pp. 67-94). Amsterdam: John Benjamins.

Lee, G. (2002). Kankokugo bogowasha no sutairu kirikae [Code-switching by native Korean JSL learners]. Handai Shakaigengogaku Kenkyu Nooto, 4, 73-93.

MacWhinney, B. (2000a). The CHILDES project: Tools for analyzing talk, Transcription format and programs (Vol. 1). (3rd ed.) Mahwah, NJ: Lawrence Erlbaum Associates.

MacWhinney, B. (2000b). The CHILDES project: Tools for analyzing talk, The database (Vol. 2). (3rd ed.). Mahwah, NJ: Lawrence Erlbaum Associates.

Marriott, H. (1993). Acquiring sociolinguistic competence: Australian secondary students in Japan. Journal of Asian Pacific Communication, 4 (4), 167-192.

Marriott, H. (1995). The acquisition of politeness patterns by exchange students in Japan. In B. F. Freed (Ed.), Second language acquisition in a study abroad context (pp. 197-224). Amsterdam: John Benjamins.

Marriott, H. (1997). The language learning experiences of exchange students in Japan. Dainigengo toshite no nihongo no shuutoku kenkyuu, 1, 29-56.

McDonough, J., \& McDonough, S. (1997). Research methods for English language teachers. London: Arnold.

Minegishi, R. (1999). Nihongo gakushuusha e no shukuyakukei no meyasu: Nihonjin ni yoru hyooka to shiyooritsu o fumaete [A standard for the teaching of contracted forms to learners of Japanese: Based on the evaluation and conversational use of native speakers]. Nihongo Kyooiku, 102, 30-39.

Neustupny, J. V. (1985a). Problems in Australian-Japanese contact situations. In J. B. Pride (Ed.), Cross-cultural encounters: Communication and miscommunication (pp. 44-64). Melbourne: River Seine.

Neustupny, J. V. (1985b). Language norms in Australian-Japanese contact situations. In M. G. Clyne (Ed.), Australia, meeting place of languages (pp. 161170). Canberra: Pacific Linguistics.

Neustupny, J. V. (1990). The follow-up interview. Japanese Studies Association of Australia Newsletter 10 (2), 31-33.

Neustupny, J. V. (1994a). Nihon kenkyuu no hoohooron: Deeta shuushuu no dankai [Methodology of Japanese research: The stage of data collection]. Taikenzanronsoo: Nihongogakuhen 28, 1-24.

Neustupny, J. V. (1994b). Problems of English contact discourse and language planning. In T. Kandiah \& J. Kwan-Terry (Eds.), English and language planning: A Southeast Asian contribution (pp. 50-69). Singapore: Times Academic Press. 
Neustupny, J. V. (1997a). Teaching communication or teaching interaction? Ibunka Komyunikeeshon Kenkyuu [Kanda University of Foreign Languages], 10, 1-13.

Neustupny, J. V. (1997b). Purosesu toshite no shuutoku no kenkyuu [The study of language acquisition as a process]. Handai Nihongo Kenkyuu, 9, 1-15.

Nishi, Y., \& Shirai, Y. (2004). Kaiwa ni okeru teiru no imi [Semantics of -te iru in conversation]. In M. Minami \& M. Asano (Eds.), Gengogaku to Nihongo Kyooiku 3 (pp. 231-249). Tokyo: Kuroshio Shuppan.

Oshima-Takane, Y., \& MacWhinney, B. (1995). CHILDES manual for Japanese (revised in 1998). Montreal: McGill University.

Regan, V. (1995). The acquisition of sociolinguistic native speech norms: Effects of a year abroad on second language learners of French. In B. F. Freed (Ed.), Second language acquisition in a study abroad context (pp. 245-267). Amsterdam: John Benjamins.

Sanada, S., Shibuya, K., Jinnouchi, M., \& Sugito, S. (1992). Shakaigengogaku [Sociolinguistics]. Tokyo: Oofuu.

Sawyer, M. (1992). The development of pragmatics in Japanese as a second language: The sentence-final particle ne. In G. Kasper (Ed.), Pragmatics of Japanese as a native and target language (pp. 83-125). Honolulu: University of Hawaii, Second Language Teaching and Curriculum Center.

Sheu, S. (1997). Chuujookyuu taiwanjin nihongo gakushuusha ni yoru teiru no shuutoku ni kansuru oodan kenkyuu [A cross-sectional study of the acquisition of -te iru by intermediate and advanced Taiwanese learners of Japanese]. Nihongo Kyooiku, 95, 37-48.

Sheu, S. (2000). Shizen hatsuwa ni okeru nihongo gakushuusha ni yoru teiru no shuutoku kenkyuu: OPI deta no bunseki kekka kara [Acquisition study of -te iru in natural speech by Japanese learners: Based on an analysis of OPI data]. Nihongo Kyooiku, 104, 20-29.

Sheu, S. (2002). Nihongo gakushuusha ni yoru teita no shuutoku ni kansuru kenkyuu [A study of the acquisition of -te ita by Japanese learners]. Nihongo Kyooiku, 115, 41- 50.

Shibata, M. (1998). The use of Japanese tense-aspect morphology in L2 discourse narratives. Dainigengo toshite no Nihongo Shuutoku Kenkyuu, 2, 68-102.

Shirai, Y., \& Kurono, A. (1998). The acquisition of tense-aspect marking in Japanese as a second language. Language Learning, 48 (2), 245-279.

Siegal, M. (1994). Second-language learning, identity, and resistance: White women studying Japanese in Japan. In M. Bucholtz, A. Liang, L. Sutton, \& C. Hines (Eds.), Cultural performances: Proceedings of the third Berkeley women and language conference (pp. 642-650). Berkeley, CA: Berkeley Women and Language Group.

Siegal, M. (1995). Individual differences and study abroad: Women learning Japanese in Japan. In B. F. Freed (Ed.), Second language acquisition in a study abroad context (pp. 225-244). Amsterdam: John Benjamins. 
Siegal, M. (1996). The role of learner subjectivity in second language sociolinguistic competency: Western women learning Japanese. Applied Linguistics, 17 (3), 356-382.

Silverman, D. (2000). Doing qualitative research: A practical handbook. London: Sage.

Sugaya, N. (2003). Nihongo gakushuusha no asupekuto shuutoku ni kansuru jyuudan kenkyuu: Doosa no jizoku to kekka no jootai no teiru o chuushin ni [A longitudinal study on the acquisition of imperfective aspect morphology by L2 learners of Japanese: Focusing on the progressive and the resultative state use of -te iru]. Nihongo Kyooiku, 119, 65-74. 